Journal of Educational Method and Technology Vol. 2 No. 3, Desember 2019

P-ISSN 2622-8459 E-ISSN 2622-8467

http://ejournal.unima.ac.id/index.php/jemtec

\title{
Digital Media and Students' Writing Ability
}

\author{
N V F Liando ${ }^{1}$, S Martha ${ }^{2}$ \\ ${ }^{1,2}$ Universitas Negeri Manado, Indonesia \\ corresponding author: ${ }^{1}$ nithaliando@unima.ac.id
}

\begin{abstract}
With the development of information and technology nowadays, schools need to adapt and make changes. This research aims to investigate the application of digital media in improving students' ability in writing a report text. This research was done in one class at one high school in North Sulawesi. The eighth-grade students consist of 30 students. In this study, digital media used was power point presentation. In collecting the data, the researcher worked collaboratively with the English teachers in the school in which Classroom Action Research was employed. The research was conducted in two cycles which there were four steps each cycle: planning, observing, acting and reflecting. The data were collected through observation check list and conducting the test after implementing each cycle. The result of each cycle showed that students writing ability was increased. The result of test in cycle 1: 76.73 and in cycle 2: 81.06. This result leads to a conclusion that students' ability in writing report text increased. Thus, it could be recommended that writing report text should be taught using an interesting digital media like power point presentation
\end{abstract}

Keywords: Digital media, Writing Skill, report text, CAR.

\section{Introduction}

Teaching English to students is not an easy work. Teachers have to pay sufficient attention to students' attention during learning process. In fact, teachers always teach the students by giving them complete explanation about the lesson. However, the problem for students is sometimes they cannot receive or understand the lesson very well because teacher's presentation about the lesson does not interest for them. Teacher does not have to force them to remember many new words but to let them enjoy the learning process.

Observations done in schools gave enough information that many students faced some difficulties in learning English especially in writing. Some problems caused the difficulties students facing, among others students seldom practice to write composition even in their native language, they are lack of vocabulary and knowledge about genre or text type, and they spend much time to think what they should write because they have no idea how to write it. Some strategies that the teachers use to teach the students in writing does not adequately motivate and 
encourage them. Even worse, many teachers got troubles to teach this skill to the students.

Writing is an active written language skill. Through writing students may express their idea freely without having to face the reader directly. Writing is creative and expressive process. Students need to explore their ideas and compose into a good text. In order to produce a good writing, students are expected to understand aspect of writing including the text organization, the language features, the mechanic and the choices of words and vocabularies. One of the text types in writing is report text. Report text is a text that explain about living plants, animals and non-living things like phones, bikes, or oceans (Derewianka, 1990).

One of the techniques in developing student's writing ability is by using Power Point presentation. This makes them interest and easy to understand what they have to write. In fact, many students in this school felt difficult to express their idea in written form, to make simple paragraph. Men who learn English as a foreign language often say that writing is more difficult than any other skills.

Students learn through activities. In order to learn, they must act or react; they may read, they may listen to the teacher, they may practice the language. To encourage students to get involved in these activities, teacher should create a favorable atmosphere. Clark (1981:55) explains, "In a bright and cheerful atmosphere, pupils are more likely to become interested in their school work and perform it. Therefore, you should strive for a pleasant classroom".

The statement above indicates that students will learn better in a pleasant classroom atmosphere. They may be actively involved in teaching - learning activities, such as in asking question, doing a dialogue and doing exercises. During the language teaching and learning activities in the classroom; the teacher functions as a counselor (Larsen, 1986:100) which means that the teacher recognizes how threatening a new learning situation can be for learners.

Teaching English for the basic knowledge of language can help students to increase their skills. Teaching can mean that a counselor must respond to the learners' needs individually and rather than only teaching them, the counselor has to understand language and learning strategies to help learners learn how to teach (Dickinson,1987). Counselor is the teacher, teacher as the educator has the important role to manage teaching and learning process in order to make students enjoy the activities in classroom and understand the lesson that is taught by the teacher.

Writing is a way of communicating a message to a reader as a purpose. The purposes of writing are to express one's self, to provide information for one's reader, to persuade one's reader and to create a literary work. Troyka (1987:3-4). Writing skills are an important part of communication. Good writing skills allow you to communicate your message with clarity and ease to a far larger audience than through face to face or telephone conversations.

Writing is one of the four skills to be learned in school. It is the activity learning process. Learning to write is a process where the students learn to use ideas and facts. In this we must proceed by stages from simple to complex. The term of ability is defined as skill or power. Concisely, writing ability is the skill to express ideas, thoughts, and feelings to other people in written symbols to make other people or readers understand the ideas conveyed. 
Technology is very popular for people in the world in this era. Most people are interested to use technology to finish their job early. For instance, finishing job at office early, spending time with playing video games or application in a smart phone, communicate with other people by using mobile phone, creating a job by using internet connection, etc. Technology is used in many aspects of human life. It is also included in education progress. Bringing technology in the classroom is a very interesting idea for educator to make creative activities in class to help students to understand the lesson. Lockard (1993:217-23) defines multimedia as 'any system that unites two or more media into a single product or presentation' where multimedia are divided into two components, the hardware and the software.

Warsahauver and Meskil (2000) recognize multimedia based simulation software as a tool which is able to expose language learners to culture and linguistic worlds in a meaningful way through audio and visual settings. Multimedia tools include computer-generated sound, graphics and animation, along with sound and visual forms (Forcier and Descy 2002) and exploited purposefully, enriches a computer assisted learning environment through interactive learning ( $\mathrm{Neo}$ and $\mathrm{Neo}$, 2002). Power point is a part of multimedia presentation.

Media is an excellent way to pose assessment question for the class to answer or students can submit mediated presentation as classroom projects. Meanwhile, Brown, Lewis and Halcleroad (1983) state that the function of media are: (1) to save time; (2) to stimulate interest; (3) to encourage students participation;(4) to provide review; (5) to help students to learn communicative ideas visually;(6) to provide a medium for individual or group reports; (7) to make a classroom dynamic, relevant , and attractive. Therefore, the researcher decided to choose power point as a media to encourage students to write.

This study focused on report text. Report texts present information about something, as it is a result of systematic observation and analysis. The purpose of the text report is to describe and classify information. Text report has a series logical truth. It is stated the facts without personal involved personal involvement.

In writing report text, the following were used: general nouns rather than particular nouns, timeless present tense to indicates usualness or Simple present tense, except when it is past then used the simple past tense, action verbs, to describe behavior such as make, begin, surround and do not used personal pronouns (I, You, We) because there was no personal involvement, relational verb to described and classify features (is, are, have), technical terms, paragraphs with topic sentences to organize bundles of information; repeated naming of the topic as the beginning focus of the clause.

The generic structure of report text:

1) Title: a title describes the subject being discussed;

2) General classification: Stating classification of general aspect of thing: animal, public, place, plant;

3) Description: Tell what the phenomenon under discussion: In terms of parts, qualities, habits, or behaviors and describing the thing which will be discussed in detail: part per part, custom or deed for living creature and usage for materials. 
Journal of Educational Method and Technology Vol. 2 No. 3, Desember 2019

P-ISSN 2622-8459 E-ISSN 2622-8467

http://ejournal.unima.ac.id/index.php/jemtec

\section{Methods}

The design applied in this research is a Classroom Action Research (CAR). This is based on the reason that the writer aims at solving the students' problem in writing skill in order to improve their writing ability. In this research, the researcher collaborates with one of the English teachers at the school who helps her in the process of collecting the data and in analyzing the data. Here, the researcher acts as the teacher who conducts the process of teaching and learning in the classroom. The procedures of this action research refer to the model of Lewin (1990:97) which consists of four steps. They are planning, action, observation, and reflection. These phases take place in every cycle in which the analysis of the weaknesses and the strengths of the activities applied is discussed.

The planning is based on the findings of the preliminary observation. The setting of the school and the students as well as the teachers' background from all aspects which are considered influencing the students' success in learning English, especially on writing skill are analyzed. The findings, then become the basic consideration to plan the strategy used in teaching writing. The strategy to be developed in this study emphasizes on the activities individually. While implementing the plan in the next step, the observation takes place in the same time. The data from the observation are to be analyzed to see whether the strategy applied can solve the students' problem in improving writing skill. The strategy is then revised accordingly for the next cycle. The cycle is stopped when the criteria of success are met.

In analyzing the data, the researcher uses qualitative and quantitative data procedures. To see the students' activity during the teaching and learning process, the researcher analyzes and presents the data qualitatively. The researcher gets the answer by analyzing the data based on the explanation and conclusion obtained from the observation checklists. Meanwhile, to see the students' improvement on writing skill, the researcher uses the procedure of quantitative data. Considering the difficulties of writing skill and the students' ability in writing as it is recorded in the preliminary study, the researcher stops the cycle when $80 \%$ of the students are in the level of good (two indicators are fulfilled).

This research investigated students' development in learning writing through Power Point Presentation. The population was students of one high school in North Sulawesi. The sample was taken ninth grade A students. There are 30 students, consist of 22 female students and 8 male students.

In conducting this research, the researcher uses qualitative and quantitative data. The qualitative data are taken from the students' participation in writing activities, comments, opinions and suggestions of the students got from the result of observation and field note about the strategy applied during the teaching and learning process in each cycle. Meanwhile, the students' ability on writing skill showed in the observation sheet belongs to the quantitative data. Descriptive analysis used the mean score $\bar{X}$ and standard deviation (s) the scores were computed with the method use by Karavas-Doukas (1995).

\section{Finding and Discussion}

This research was done in two cycles. Cycle 1 was conducted in two meetings. The planning, the action, the observation, and reflection of this cycle are 
presented in this part. The researcher introduced the strategy that used in improving students' ability in writing a report text. There were some related media prepared by the researcher to apply this strategy which are projector and laptop. The four steps were described as follows.

\section{Planning}

The lesson plans are designed for two meetings each of which is focused on the use of power point presentation to solve the students' problem in writing. The theme discussed in this cycle is "What are They". The strategy of writing activities developed here is all directed to enable the students to write simple paragraph. In this part, the researcher prepared the observation checklist. Then, teacher explained about kinds of characteristics using in describing animals generally, such as Physical characteristic, Habitat, Color, Size, Food/Diet, Habit and Traits. Teacher prepared the interesting media. During the two meetings, the teacher showed the media such as some of pictures related to the topic in the slides. using Power Point Presentation.

\section{Acting: First Meeting}

In the beginning of the class, the researcher uses ten minutes of the session to prepare English subject. This includes greeting, opening class with pray, checking the students' attendance, giving motivation, apperception and inform the learning objectives. In pre-activity the teacher showed some pictures at slide of power point and then the students gave comments. It was used for brainstorming to open up their mind. After that teacher explained general structure and noun phrase for describing animals' characteristic such as physical characteristic, color, size, food/diet, habits, habitat, and traits. In the whilst activity, students worked in pairs to describe animals' physical characteristic based on the picture shown on the slides of power point, in the form of noun phrase. Next session, the students joined the group to determine the animals' characteristic together they come in front of the class to explain each parts of characteristic. At the end of class, researcher and students concluded the topic had learned, give homework, described the topic for next meeting, give award to the students and finally ask one student for closing with pray.

\section{Second Meeting}

In the beginning of the class, the researcher uses ten minutes of the session for in-class preparation. This includes greeting, opening class with pray, checking the students' attendance, giving motivation, apperception and informing about the learning objectives, activities at the classroom when the researcher implementing the strategy and the students' activities. Then, teacher showed the pictures using power point and the students observed it. Each slide has keywords, it is easy for students to arrange sentences and then improved become a simple of report text. The main activity in this session is the students write a report text using power point strategy. Finally, students submitted their result and teacher would give them feedback how about their writing one by one. At the end, teacher scored the students based on the criteria (Content, Organizing and Language). Teacher asks the student for closing with pray. 
Journal of Educational Method and Technology Vol. 2 No. 3, Desember 2019

P-ISSN 2622-8459 E-ISSN 2622-8467

http://ejournal.unima.ac.id/index.php/jemtec

\section{Observing}

The researcher made an observation checklist to examine students' respond in writing a report text using PPP. This was prepared by the researcher and her collaborator. When the researcher was doing the activity at the classroom, her collaborator checked students' interest in observation checklist.

In the first cycle, researcher already given a written test to the students. This cycle divided in two meetings. The percentage of students' result was described in the table 1 .

Table 1 Students' percentages based on the result in first cycle

\begin{tabular}{|c|c|c|c|c|}
\hline NO & SCORE & Average & $\begin{array}{c}\text { PERCENTAGE } \\
(\%)\end{array}$ & Rating Level \\
\hline 1. & $\mathbf{0 - 4 9}$ & $\mathbf{0}$ & $\mathbf{0}$ & Very Bad \\
2. & $\mathbf{5 0 - 6 9}$ & $\mathbf{5}$ & $\mathbf{1 7 \%}$ & Bad \\
3. & $\mathbf{7 0 - 8 0}$ & $\mathbf{2 2}$ & $\mathbf{7 3 \%}$ & Good \\
4. & $\mathbf{8 1 - 1 0 0}$ & $\mathbf{3}$ & $\mathbf{1 0 \%}$ & Very good \\
\hline & Total & $\mathbf{3 0}$ & $\mathbf{1 0 0} \%$ & \\
\hline
\end{tabular}

Five students got 50-69 (17 \%), twenty-two students got $70-80(73 \%)$ and three students got $81-100(10 \%)$.

\section{Reflection}

In the reflection, researcher and her collaborator agreed to conclude that there were some students who still did not understand teachers' explanation and they were still confused to organize the text. Finally, researcher and her collaborator discussed the solution to overcome this problem, so that learning process in the next cycle would be better.

\section{Second Cycle}

Planning

Before the teaching and learning activities started the researcher and her collaborator had some discussions about what to do in the second cycle. Some preparations are made including the lesson plan, the instructional materials and the media.

The lesson plans are designed for two meetings, each of which focused on the use of power point presentation to solve the students' problem in writing. The theme discussed in this cycle is "What are They". The strategy of writing activities developed here is all directed to enable the students to write in simple paragraph. In this part, the researcher prepared the observation checklist for known the students' respond in applying this strategy.

The division of students individually is the next thing to be discussed and planned well before taking the action in the first cycle. There are 30 students with different ability of English especially on writing skill which appear in grade ninth.

\section{Acting}

When all preparations are ready. The researcher, as the teacher, implemented the activities that have been designed using power point presentation. The subject is ninth grade students. 


\section{Third Meeting}

In this meeting, at first the researcher uses ten minutes of the session to prepare English subject. This includes greeting, opening class with pray, checking the students' attendance, giving motivation, apperception and inform about the learning objectives. In pre-activity the teacher showed some pictures at slide of power point and then the students give comments, it was used for brainstorming or open up their mind, after that teacher explain about general structure and noun phrase for describing animals' characteristic such as physical characteristic, color, size, food/diet, habits, habitat, and traits. In the whilst activity, students worked in pairs to describe animals' physical characteristic based on the picture shown at the slide of power point, in form of noun phrase. In the following session, the students joined the group to determine the animals' characteristic together they come in front of the class to explain each parts of characteristic. At the end of class, researcher and students concluded topic had learned, give homework, described the topic for next meeting, gave award to the students and finally ask one student for closing with pray.

\section{Fourth Meeting}

This meeting starts with greeting, opening class with pray, checking the students' attendance, giving motivation, apperception and inform about the learning objectives. The activities at the classroom when the researcher implementing the strategy that the students' activities. In the beginning of the class, the researcher uses ten minutes of the session to prepare English subject. Then, teacher showed the picture using power point and the students observed it. Each slide has keywords, it would be easy for students to arrange sentences to become a simple of report text. The main activity in this session is the students write a report text using power point strategy. Finally, students submitted their result and teacher gave them feedback how about their writing one by one. At the end, teacher scoring the students based on the criteria (Content, Organizing and Language). Teacher asked the students for closing with pray.

\section{Observing}

The researcher made an observation checklist again to identify more about students' responses in writing a report text using PPP. This was prepared by the researcher and her collaborator. When the researcher was doing the activity at the classroom, her collaborator checked students' interest in observation checklist. At the end of the cycle, researcher gave a written test to the students. The percentage of students' result can be seen in Table 2: 
Journal of Educational Method and Technology Vol. 2 No. 3, Desember 2019

P-ISSN 2622-8459 E-ISSN 2622-8467

http://ejournal.unima.ac.id/index.php/jemtec

Table 2. Students' percentages based on the result in second cycle

\begin{tabular}{|c|c|c|c|c|}
\hline No. & Range Score & $\begin{array}{c}\text { Number of } \\
\text { Students }\end{array}$ & $\begin{array}{c}\text { PERCENTAGE } \\
(\%)\end{array}$ & $\begin{array}{c}\text { RATING } \\
\text { LEVEL }\end{array}$ \\
\hline 1. & $0-49$ & 0 & 0 & Very Bad \\
2. & $50-69$ & 0 & 0 & Bad \\
3. & $70-80$ & 16 & $54 \%$ & Good \\
4. & $81-100$ & 14 & $46 \%$ & Very good \\
\hline & Total & 30 & $100 \%$ & \\
\hline
\end{tabular}

This shows that there were not a student got the lower score 0-49, 50-69, sixteen students got 70-80 ( $54 \%$ ) and fourteen students got the higher score 81-100 (46\%). It means that students' ability in writing a report text about $100 \%$.

\section{Reflection}

In the reflection, researcher and her collaborator made a conclusion based on the observation result that some students have improved in writing a report text, how to organize the text and described animals.

The use of power point presentation which are capable to increase students' interest because the students can generate their ideas and focus in writing. The students were able to write not only one paragraph but more. This technique made the students able to express many ideas and write more than they had done before. Their work also showed good results. This means that the presence of power point presentation was able to enhance their ability to focus and concentrate on the topic they were going to write. The important function of visual media is that they attract and focus students' attention to concentrate on the lesson material (Arsyad, 2002).

\section{Conclusions}

Students like to learn writing through power point media. They became interest in writing and understand how to write. They felt comfortable in following the process with many interesting subjects, like pictures, sounds and video provided by the teacher in power point media. It helped students to pay attention and understand the lesson. Students also develop their English skill and was successful to increase their score of the subject. The result was clear, that the students have improved their writing ability in writing report text using power point presentation. Learning writing using power point presentation made students easier to understand the lesson and increased their interest in writing report text. It is recommended that future research would use other digital media in English learning process for more complete and creative teaching strategy than the previous one.

\section{References}

Arsyad, A. (2002). Media Pembelajaran. Jakarta: PT.Raja Grafindo Persada.

Brown, J., Lewis R.B., \& Harcleroad, F.F. (1983). Audio visual instruction. New York: McGraw Hill Book Inc.

Clark L.H. AND Starr, I.S. 1981.Secondary and Middle School Teaching Method. New York: McMillan Publishing Co. Inc 
Journal of Educational Method and Technology Vol. 2 No. 3, Desember 2019

P-ISSN 2622-8459 E-ISSN 2622-8467

http://ejournal.unima.ac.id/index.php/jemtec

Derewianka. 1990. What is the meaning of report text. From http://.www.01/what is the meaning of report text/ paradisarizki. Wordpress accessed on 15 October 2015

Dickinson, L. (1987). Self-instruction in Language Learning. Cambridge: Cambridge University Press.

Forcier, R.C. \& Descy, D.E (2002) The computer as an educational tool: Productivity. Cambridge: Cambridge University Press.

Karavas-Doukas, E. (1995). Teacher identified factors affecting the implementation of an EFL innovation in Greek public secondary schools. Language, Culture and Curriculum, 8(1), 53-68.

Lewin, Kurt. (1990). Action Research and minority Problems the Action Research Reader. Victoria: Deakin University.

Lockard , J , Abrams. P. D \& Many, W. A. 1993. Microcomputers for twenty first century educators. $3^{\text {rd }}$ ed. New York: HarperCollins Publisher Inc.

Troyka. (1987). Definition of writing ability. http://en.teachingenglishonline.net/definition-of-writing-ability accessed on 10 December 2014

Warchauver, M. \& Meskill, C. (2000). Teaching and second language learning . In J. Rosenthal (Ed), Handbook of undergraduate second language education (pp. 303-318). Mahwah, New Jersey: Lawrence Erlbaum. Retrieved July 11, 2005 
Journal of Educational Method and Technology Vol. 2 No. 3, Desember 2019

P-ISSN 2622-8459 E-ISSN 2622-8467

http://ejournal.unima.ac.id/index.php/jemtec 